\title{
Hyperleucocytosis grading score and NPM1 gene mutation among patients with acute myeloid leukemia: Malaysian experience
}

\author{
Uday Younis Hussein Abdullah ${ }^{1}$ (D) Nordin Simbak ${ }^{1} \cdot$ Marwan Saad Azzubaidi $^{1} \cdot$ Raudhawati Osman $^{2}$. \\ Hishamshah M. Ibrahim ${ }^{2}$. Haitham Muhammed Jassim ${ }^{3}$ - Noraini Mat Yunus ${ }^{4}$. Muhammad Farid Johan ${ }^{4}$. \\ Zilfalil Bin Alwi ${ }^{4}$. Lay Kek Teh ${ }^{5} \cdot$ Mohd Nur Fakhruzzaman $^{5} \cdot$ Mohd Zaki Salleh $^{5}$
}

Received: 3 June 2019 / Accepted: 14 November 2019 / Published online: 3 January 2020

(C) Springer-Verlag GmbH Germany, part of Springer Nature 2020

\begin{abstract}
This is the first study evaluating the frequencies of nucleophosmin (NPM1) gene mutation according to the hyperleukocytosis (HL) grading score. The current two cut off values of this score in acute myeloid leukaemia (AML) patients are [1] those with 50$100 \times 10^{9} / \mathrm{L}$ and [2] those with $\geq 100 \times 10^{9} / \mathrm{L}$ total WBC count. The score represents the current clinically based definition of HL in patients with AML. A total of 90 patients with AML were included. AML patients were stratified into three groups: [1] those with a WBC count below $50 \times 10^{9} / \mathrm{L}(n=33)$, [2] those with a WBC count 50-100 $\times 10^{9} / \mathrm{L}(n=29)$ and [3] those with a WBC above $100 \times 10^{9} / \mathrm{L}(n=28)$. Complete blood cell count, immunophenotyping and PCR of the exon 12 of NPM1 gene followed by sequencing analysis were done. NPM1 mutations were detected in 20/90 (22.2\%) of patients with AML involving exon 12 of NPM1 gene and showed significant correlations with some hematologic characteristics. Contrary to expectation, no statistically significant difference was found in the WBC counts according to the NPM1 gene the mutation status among the studied groups. Also, there were no significant differences in the WHO classification categories according to the HL grading score. The difference in the frequency of NPM1 mutation in Asian compared to Western patients might be attributed to biology and aetiology variation of the disease in different population. The current two cut off values defining the HL are molecularly unreliable in spite of being clinically defined.
\end{abstract}

Keywords Hyperleucocytosis $\cdot$ Grading score $\cdot$ NPM1 gene $\cdot$ Mutation $\cdot$ Acute myeloid leukaemia $\cdot$ Malaysia

Uday Younis Hussein Abdullah

udayyounis@unisza.edu.my

1 Faculty of Medicine, Universiti Sultan Zainal Abidin, Medical Campus, 20400 Kuala Terengganu, Terengganu, Malaysia

2 Pathology department, Haematology unit, Hospital Kuala Lumpur (HKL), Jalan Pahang, 50586 Kuala Lumpur, Malaysia

3 Emergency Department, Rockingham Peel Group, South Metropolitan Health Service, Rockingham 6967, West Australia, Australia

4 School of Medical Science, Health Campus, Universiti Sains Malaysia (USM), 16150 Kubang Kerian, Kelantan, Malaysia

5 Integrative Pharmacogenomics Institute (iPROMISE), Universiti Teknologi MARA (UiTM) Campus Selangor, 42300 Bandar Puncak Alam, Selangor, Malaysia

\section{Introduction}

Reliability of hyperleukocytosis (HL) grading scores and its correlation with the frequency of the NPM1 gene mutation in acute myeloid leukaemia (AML) has not been verified to date. AML is a phenotypically and genetically heterogeneous clonal disorder of hemopoietic myeloid stem cells characterized by the inhibition of differentiation, accumulation of cells at various stages of incomplete maturation, reduced production of normal hemopoietic elements and variable responsiveness to therapy [1]. Genetic-based analyses and molecular markers are now established as the central component for accurate diagnosis, prognostic stratification, monitoring minimal residual disease and developing targeted therapies [2]. NPM1, also known as nucleolar phosphoprotein B23, numatrin1 or NO38 is a ubiquitously expressed nucleolar phosphoprotein that shuttles between the nucleus and cytoplasm with predominant nucleolar localization. In humans, NPM1 gene is implicated in the genesis of different cancers and its role in AML was well 
reviewed $[3,4]$. As a general rule, the presence of an NPM1 mutation is associated with a more favourable clinical outcome [2]. The NPM1 mutation was discovered in 2005 and represents the most frequently observed molecular abnormalities in about $50 \%$ of AML cases $[3,5,6]$.

NPM1 was first identified as a nucleolar phosphoprotein that has a role in the regulation of cell growth, proliferation and transformation. Translocations of the mutated NPM (NPMm) protein into the cytoplasm are the most specific and frequent events found in AML with a normal karyotype that will have a good response to induction chemotherapy [5]. Cytogenetic location of NPM1 is $5 \mathrm{q} 35.1$ with a size of $25 \mathrm{kbp}$. Exon 12 of NPM1 with a size of 650 bp encodes a ubiquitously expressed $37 \mathrm{kDa}$ protein that is localized at the nucleolus $[5,6]$. Other functions for this protein include regulation of centrosome duplication; ribosomal function; stress-induced regulator of p53 in response to hypoxia, UV irradiation or cytotoxic drugs [7]; molecular chaperone that have role in preventing both proteins and nucleic acids aggregation in the nucleolus; regulation of the assembly; transport of preribosomal particles through the nuclear membrane; progression of cell cycle; regulation of the p53 tumour suppressor pathway and stabilization and nucleolar localization of p14ARF $[8,9]$. The cytoplasmic displacement of NPM1 and the mutation of exon 12 were described as being a hallmark of a large AML subgroup [10]. AML with mutated NPM1 shows distinctive biological and clinical features, and is therefore, categorized as a provisional entity in the World Health Organization classification of leukemias. To date, the presence of this genetic lesion does not define specific disease entities [4]. AML with NPM1 gene mutation encompasses all the WHO categories, and it represents leukemic entity accounting for approximately one-third of all AML [7, 10-14].

$\mathrm{HL}$ in acute leukemias has been variably defined as a total white blood cells (WBC) count of more than 50 or $100 \times 10^{9} /$ $\mathrm{L}$ [15]. This definition is based on clinical parameters which took into consideration the WBC level at which leukostasis occur more frequently [16]. To date, the reliability of the correlation of these grading scores of HL with the NPM1 gene mutation was not verified. The WBC count significantly affects blood viscosity in the microcirculation of the lung, brain and heart at a level exceeding $50 \times 10^{9} / \mathrm{L}$ and the risk increases significantly with $\mathrm{WBC} \geq 100 \times 10^{9} / \mathrm{L}$. HL with leukostasis is a medical emergency caused by the blast cell aggregates and thrombi formation in the microcirculation resulting in clinically observed signs and symptoms. The underlying mechanisms leading to the development and the progression of $\mathrm{HL}$ are still unclear $[17,18]$.

The overall objective was to evaluate the reliability of the two grading scores of HL based on the frequencies of NPM1 gene mutation. Specific objectives were to assess the types and frequencies of NPM1 gene mutation in AML patients with $\mathrm{WBC}$ count $<50 \times 10^{9} / \mathrm{L}$, compared to frequencies of the NPM1 gene mutation in patients with WBC count between 50 and $100 \times 10^{9} / \mathrm{L}$ and those with $\mathrm{WBC}$ count $>100 \times 10^{9} / \mathrm{L}$. Mutations in exon 12 of NPM1 are the most frequently acquired molecular abnormality in $\mathrm{AML}$ occurring with an overall frequency of $25-35 \%$. [1, 2]. NPM1 mutations have been reported in 50-60\% of adults with de novo AML, especially those with a normal karyotype $[5,6,19,20]$. Generally, patients with NPM1 mutation express substantially higher WBC count than those with the wild type. Additionally, those patients were found to possess significantly lower CD34 antigen expression on flow cytometry [21]. Among NPM1-mutated AML, the antigen expression pattern of $\operatorname{HLADR}(+) \mathrm{CD} 34(+) \mathrm{CD} 7(+)$ is associated with a poor prognosis [22]. A variety of molecular methods for detecting NPM1 mutations have been employed including PCR amplification and direct sequencing, high-resolution fragment analysis, melting curve analysis on the Light Cycler system, denaturing high-performance liquid chromatography (DHPLC), LNA-mediated PCR clamping, flow cytometer, a western blot assay using polyclonal antibodies, FAST PCR assay and quantitative PCR [22-25].

\section{Methodology}

Ethical approval was obtained from UniSZA (UniSZA/C/2/ CRIM/628-1 [25]) and National Medical Research Register (NMRR-13-1487-1712).

This is a cross-sectional study which enrolled a total of 90 patients with newly diagnosed (de novo) or relapsed AML with or without abnormal karyotypes. Patients with secondary acute leukaemia were excluded. All blood and bone marrow samples were obtained at the time of initial diagnosis. The classification of AML followed the WHO classification 2008. Diagnosis of AML and its subtype were confirmed by cytological examination and immunophenotyping of blood and bone marrow. Briefly, blast cell determination was expressed as the percentage out of all the bone marrow nucleated cells. The differential WBC count was typically based on a 200-cell count in peripheral blood and 500-cell count in the blood marrow. The total 90 patients with AML enrolled in this study were stratified into three groups: group 1 were those with a WBC count below $50 \times 10^{9} / \mathrm{L}(n=33)$, group 2 were those with a WBC count between 50 and $100 \times 10^{9} / \mathrm{L}(n=29)$ and group 3 were those with a WBC above $100 \times 10^{9} / \mathrm{L}(n=$ 28). Peripheral blood or bone marrow samples or unstained bone marrow smears were used for genomic DNA (gDNA) extraction. The unstained bone marrow smears were scraped off the surface of the microscope slides in a laminar flow hood using a sterile scalper blade. Separate blade was used for each patient's smears. The scraped material was hydrated in a sterile $3.0 \mathrm{ml}$ tube contained $2.0 \mathrm{ml}$ phosphate-buffered saline (PBS; 0.02 M, pH 7.4). Complete blood cell count (CBC) 
was done using modern, automated haematology system (Sysmex XE5000) (Sysmex Corp., Chuo-ku, Kobe, Japan) at HKL, Malaysia. The CBC parameters and immunophenotyping results of the patients were obtained from the patient's records.

The gDNA was extracted and purified from the peripheral blood mononuclear cells by the fully automated DNA purification instrument, QIAsymphonysp (Qiagen) using the LaboPass Genomic DNA isolation kit (Qiagen Biotechnology Malaysia Sdn. Bhd., Kuala Lumpur, Malaysia) according to the manufacturer's recommendations. gDNA quantification was based on the optical density measurement to assess the purity of extracted DNA. The concentration of DNA in solution was measured by reading the absorbance at a wavelength of $260 \mathrm{~nm}$. The gDNA was stored at $-20{ }^{\circ} \mathrm{C}$ for $2-3$ months till the analysis of the exon 12 of NPM1 gene mutation was done as described [19]. Polymerase chain reaction (PCR) amplification of the exon 12 of NPM1 gene was carried out as described using forward primer (5'-TTAACTCTCTGGTGGTAGAATGAA-3') and the reverse primer (5'-CAAGACTATTTGCCATTCCTAAC$\left.3^{\prime}\right)$ [19]. The total reaction volume was $25 \mu$ contained approximately $5 \mathrm{ng}$ DNA, $10 \mathrm{mM}$ dNTP mix each, $2.5 \mu \mathrm{l}$ of $10 \times$ PCR Buffer, $0.125 \mu$ l Master Mix (HotStarTaq DNA Polymerase $(5 \mathrm{U} / \mu \mathrm{L})), 0.25 \mu \mathrm{l}$ of each primer and $16.5 \mu \mathrm{l}$ distilled water. gDNA samples were amplified using the following PCR conditions: initial denaturation, $95^{\circ} \mathrm{C}$ for $5 \mathrm{~min}$, 40 cycles of denaturation at $94^{\circ} \mathrm{C}$ for $30 \mathrm{~s}$, annealing $55^{\circ} \mathrm{C}$ for $1 \mathrm{~min}$ and extension $72^{\circ} \mathrm{C}$ for $1 \mathrm{~min}$.

PCR products were purified by the standard methods using PCR purification Kit (Qiagen, Kenlo, Netherlands), and directly sequenced with forward primer NPM1: 5'-TTAA CTCTCTGGTGGTAGAATGAA- $3^{\prime}$ and the reverse primer NPM1: 5'-CAAGACTATTTGCCATTCCTAAC-3' (Fig. 1). The amplified DNA product was sequenced using the same primers via automated DNA sequencer according to the standard procedure with a BigDye Terminator Cycle Sequencing Kit (Applied Biosystems) on ABI Prism 3700 DNA Analyser (Applied Biosystems, Foster City, Calif). Further analysis was done using the 310 Genetic Analyser (Sanger sequencing; Applied Biosystems) (Fig. 1). DNA sequencing is the standard practice for determination of mutations in human genes.

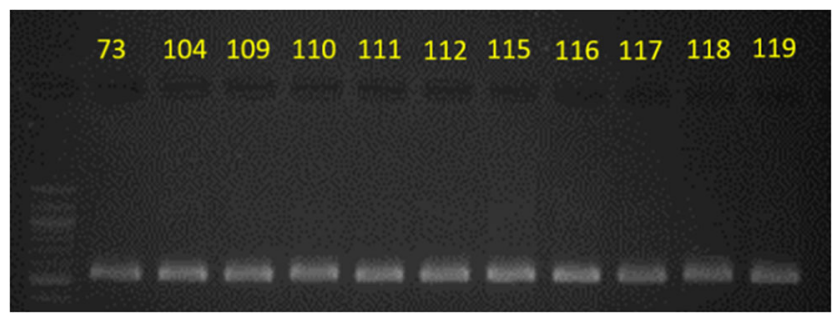

Fig. 1 Examples of the PCR products from patients' gDNA samples. Qiagen HotStarTaq DNA Polymerase amplify the targeted DNA at expected size of $358 \mathrm{bp}$
Multiple sequence alignment and analysis were conducted using Bioinformatics tool to interpret the alignments of multiple sequences (UGENE, version 1.25). All sequencing amplicons were screened for quality prior to analysis. Regions with erroneous base-calling were disregarded in the downstream analyses. Samples with highly incongruous sequences despite acceptable base-calling quality were removed from the multiple alignments. Multiple sequence alignment was performed using the ClustalOmega plugin. As a reference, the NPM1 gene sequence was acquired from the NCBI database [Homo sapiens nucleophosmin (nucleolar phosphoprotein B23, numatrin) (NPM1), RefSeqGene (LRG_458) on chromosome 5 > gi|269954735/ref/NG_016018.1].

\section{Statistical analysis}

Haematological data of patients were statistically evaluated using SPSS version 13.0 for Windows, SPSS, Chicago, IL. Sample size calculation was done using Power \& Sample Size Program version 3.0.43 which indicated the need to enrol 29 experimental subjects and 29 control subjects in order to be able to reject the null hypothesis that the failure rates for experimental and control subjects are equal with probability (power) 0.8. $p$ values $<0.05$ were considered statistically significant.

\section{Results}

The mean platelet count $\left(\times 10^{9} / \mathrm{L}\right)$ value revealed significant intergroup differences. The platelet count was found to be significantly lower in group 1 compared to those of group 3 (ANOVA test; $p$ value $=0.03$ ). However, the platelet count values in group 2 were not significantly different from both group 1 and group 3 ( $p$ value $0.39,0.39$ respectively). Mean $\mathrm{MCV}$ (fl) values showed significant higher level in group 3 (ANOVA test: $p$ value $=0.0001$ ). Mean $\mathrm{MCH}(\mathrm{pg})$ and $\mathrm{MCHC}(\mathrm{g} / \mathrm{L})$ values were significantly lower in group $3 \mathrm{com}-$ pared with group 1, while their values compared to group 2 showed no significant difference (Table 1).

No correlation was found between the other immunophenotyping variables (CD45, CD34, CD33, cMPO, CD13, CD117, HLADR, CD14, CD11b, CD11c, CD64, CD16, CD15, CD3, CD7, CD2, CD56, CD79a, CD19, CD71, CD38 and CD4) and mutation in exon 12 of the NPM1 gene in patients with AML.

Overlapping peaks in the DNA sequence chromatogram indicate the presence of NPM1 gene mutations. SNPs identified in exon 12 of the NPM1 gene were at positions 27806 (rs772573379, rs200860746), 27898 (rs1059404), 27998, 28027 (rs34351976) and 28193 (rs117701982). Two of the mutations were located upstream $(\mathrm{C} 27806 \mathrm{~T})$ and downstream (A28193G) of the exon12 region. These two mutations were removed from the analysis to rule out false or low-confidence 
Table 1 Basic haematological parameters in the studied groups

\begin{tabular}{|c|c|c|c|c|}
\hline \multirow[t]{2}{*}{ Haematological parameters } & \multicolumn{3}{|l|}{ Groups } & \multirow[t]{2}{*}{$p$ value } \\
\hline & Group $1(n=33)$ & Group $1(n=29)$ & Group $3(n=28)$ & \\
\hline Total WBC count $\left(\mathrm{X} 10^{9} / \mathrm{L}\right)$ & $\begin{array}{l}19.1 \pm 12.5 \\
1.6-42.5\end{array}$ & $\begin{array}{l}66.7 \pm 14.8 \\
44.5-89.4\end{array}$ & $\begin{array}{l}181.7 \pm 77.6 \\
100-375.6\end{array}$ & 0.0001 \\
\hline Haemoglobin $(\mathrm{g} / \mathrm{L})$ & $\begin{array}{l}80 \pm 1.8 \\
4.3-13.4\end{array}$ & $\begin{array}{l}68 \pm 2.2 \\
3.1-13.2\end{array}$ & $\begin{array}{l}77 \pm 2.5 \\
3.8-13.3\end{array}$ & 0.1 \\
\hline Platelet count $\left(\times 10^{9} / \mathrm{L}\right)$ & $\begin{array}{l}52.8 \pm 58.5 \\
6-269\end{array}$ & $\begin{array}{l}77.8 \pm 60.8 \\
16-223\end{array}$ & $\begin{array}{l}105.4 \pm 104.0 * \\
15-490\end{array}$ & 0.03 \\
\hline Bone marrow blast (\%) & $\begin{array}{l}51.4 \pm 26.2 \\
6-49\end{array}$ & $\begin{array}{l}60.4 \pm 24.7 \\
12-97\end{array}$ & $\begin{array}{l}60.6 \pm 25 \\
13-97\end{array}$ & 0.26 \\
\hline $\operatorname{MCV}(\mathrm{fl})$ & $\begin{array}{l}78.4 \pm 31.5 \\
70-123\end{array}$ & $\begin{array}{l}95.8 \pm 13.7 \\
75-132\end{array}$ & $\begin{array}{l}100.9 \pm 9.7^{*} \\
79-123\end{array}$ & 0.0001 \\
\hline $\mathrm{MCH}(\mathrm{pg})$ & $\begin{array}{l}39.1 \pm 22.9 \\
23-33\end{array}$ & $\begin{array}{l}29.4 \pm 2.8 \\
26-36\end{array}$ & $\begin{array}{l}31.3 \pm 2.7^{*} \\
26-36\end{array}$ & 0.019 \\
\hline $\operatorname{MCHC}(\mathrm{g} / \mathrm{L})$ & $\begin{array}{l}33 \pm 2.5 \\
27-38\end{array}$ & $\begin{array}{l}31 \pm 2.5 \\
27-36\end{array}$ & $\begin{array}{l}30 \pm 4.3 * \\
13-35\end{array}$ & 0.001 \\
\hline
\end{tabular}

Group $1=$ AML with a WBC count below $50 \times 10^{9} / \mathrm{L}$, Group $2=\mathrm{AML}$ with a WBC 50-100 $\times 10^{9} / \mathrm{L}$, Group $3=$ AML with a WBC above $100 \times 10^{9} / \mathrm{L}$

$M C V$ mean corpuscular volume, $M C H$ mean corpuscular haemoglobin, $M C H C$ mean corpuscular haemoglobin concentration

* $p$ value less than 0.05 compared to group 1

${ }^{\text {a }}$ ANOVA test: values represent either numbers (percentages) or as mean \pm S.D. (minimum-maximum) mutations resulting from noise (the noisy data occurred after the mutation point in the erroneous samples). Failed sequencing in some samples was due to homopolymer region (Fig. 2).

AML patients with mutation of exon 12 of NPM1 gene showed significant differences in the hematologic characteristics compared to the counterpart. The mean RBC count $(x$ $\left.10^{12} / \mathrm{L}\right), \mathrm{Hb}(\mathrm{g} / \mathrm{L})$ and $\mathrm{Hct}(\mathrm{l} / \mathrm{l})$ levels were significantly lower in the group with mutations of the exon 12 of NPM 1 gene (independent $t$ test: $p$ value $=0.01$ ). On the other hand, the mean platelet count $\left(\times 10^{9} / \mathrm{L}\right)$ and bone marrow blast percentage showed significantly lower level in the group with mutations of the exon 12 of NPM1 gene (Independent $t$ test: $p$ values $=0.006$ and 0.001 , respectively (Table 2$)$.

No statistically significant difference in the type and frequencies of mutation of the NPM1 gene among the studied groups according to the WHO classification (HL grading score) in patients with AML (Table 3).

\section{Discussion}

To the best of our knowledge, the relevance of the mutation status of NPM1 gene with WBC count according to the current clinical definition of the HL grading scores in patients with AML was not evaluated to date. A cohort of Malaysian patients with AML was investigated for the presence of mutations in exon 12 of NPM1 gene using direct sequencing approaches.
A significantly higher mean platelet count $\left(\times 10^{9} / \mathrm{L}\right)$ value in patients with WBC count higher than $100 \times 10^{9} / \mathrm{L}$ compared with those with WBC count less than $50 \times 10^{9} / \mathrm{L}$ (Table 1) as well as higher platelet count in patients with NPM1 mutation (Table 2) were detected. These findings might reflect the inability of the modern automatic blood cell analyser to identify and differentiate the small particles resulting from shedding of cytoplasmic fragments from the leukemic cells despite the use of two approaches of electrical impedance and the optical scatter in the calculation of the platelets. This finding indicates the need for clinicians' awareness of the occurrence of spuriously higher platelet count level in the situation of analysing blood samples from AML patients with HL particularly those with NPM1 mutation.

The finding of significantly lower mean $\mathrm{MCH}(\mathrm{pg})$ and $\mathrm{MCHC}(\mathrm{g} / \mathrm{L})$ values in group 3 compared with group 1 (Table 1) seems to indicate the more severe suppression of the erythropoiesis associated with increased leukemic burden as reflected by the higher WBC counts in the blood.

AML patients with mutation of NPM1 gene showed a statistically significant lower levels of the hematologic characteristics including the mean $\mathrm{RBC}$ count $\left(\times 10^{12} / \mathrm{L}\right), \mathrm{Hb}(\mathrm{g} / \mathrm{dL})$ and HCT (1/l) compared to those without mutation at $p$ value of 0.01 . The bone marrow blast percentage showed significant higher values in the group with exon 12 of NPM 1 gene mutation than those without at $p$ value 0.006 and 0.001 , respectively (Table 2). These findings might explain the more aggressive nature and behaviour of the leukemic process in patients with NPM 1 gene mutation particularly in younger age 


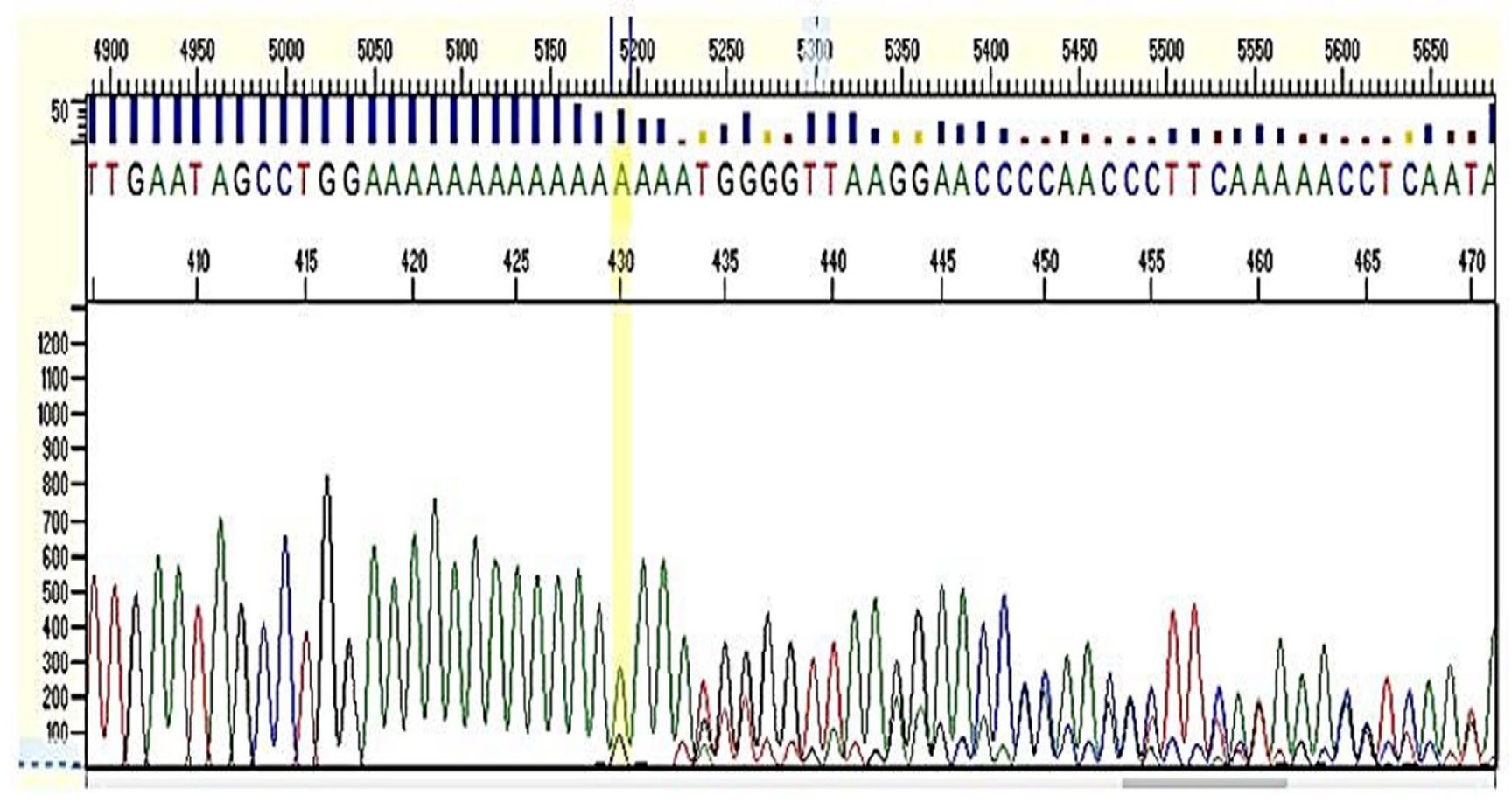

Fig. 2 Example of failed sequencing due to homopolymer region

group and reflect a variation in cellular behaviour and leukemic mechanisms in these patients with mutation of NPM 1 gene.

Screening of NPM1 gene mutations may improve risk stratification of patients with AML in the context of genetic analysis [26]. This study is the first to present a comparison of the exon 12 NPM1 mutation rate in Asian and Western patients with AML. Evidence of discrepancy in frequency of exon 12 NPM1 mutation between Asian and Western patients with AML might be attributed to variations in biology and aetiology of the disease in different population.

In studies involving Western patients, a low incidence $(6.5 \%)$ of NPM1 mutation in paediatric patients was reported [27]. NPM1 mutations were significantly less frequent in adult patients younger than 35 years [28]. A study reported that the frequencies of NPM1 mutation in relation to $\mathrm{WBC}$ count below or equal to $20 \times 10^{9} / \mathrm{L}$ compared to those with WBC count more than $20 \times 10^{9} /$ L was statistically significant [29]. Significant correlation of NPM1 gene mutation with WBC count below or equal to $80 \times 10^{9} / \mathrm{L}$ compared to those with WBC count more than $80 \times 10^{9} / \mathrm{L}$ was reported [11]. In another study, mutated NPM1 was found in $19 \%$ of AML patients with WBC count of $<20 \times 10^{9} / \mathrm{L}, 35 \%$ of patients with WBC count between 20 and $100 \times 10^{9} / \mathrm{L}$ and in $44 \%$ patients with $\mathrm{WBC}$ count $>100 \times 10^{9} / \mathrm{L}$ [9]. NPM1 mutations were investigated in 400 Southeast Asian leukaemia patients and were detectable in 105 cases $(26.25 \%)$ of AML [30].
NPM1 mutations was reported as significantly associated with higher peripheral WBC count $(p<0.05)$, and the WHO categories (AML without maturation and Acute monoblastic and monocytic leukaemia), but negatively associated with expression of CD34 $(p<0.05)$ and CD117 $(p<0.05)$ [31]. Contrary to expectation, no significant differences in the WHO classification categories according to the studied groups with HL and the NPM1 gene mutation were found (Table 3).

The number of the WHO categories of AML studied were AML with minimal differentiated 1.0 (1.1\%), AML without maturation 1.0 (1.1\%), AML with maturation $4.0(4.4 \%)$, acute promyelocytic leukaemia with $\mathrm{t}(15 ; 17) 11.0(12.2 \%)$, acute myelomonocytic leukaemia $5.0(5.6 \%)$, acute monoblastic and monocytic leukaemia $12.0(13.3 \%)$, acute erythroid leukaemia 2.0 $(2.2 \%)$, acute megakaryoblastic leukaemia (0.0) and myelodysplasia-related AML 54.0 (60\%). The reported frequency of $\mathrm{HL}$ among the WHO categories is lower in AML with maturation (20\%) and higher in acute myelomonocytic leukaemia (40\%-50\%), acute monoblastic and monocytic leukaemia (40-90\%) [14, $19,20,32]$. In the current work, the WBC count of $50-100 \times 10^{9} / \mathrm{L}$ was found in acute promyelocytic leukaemia with $\mathrm{t}(15 ; 17)$, acute myelomonocytic leukaemia, acute monoblastic and monocytic leukaemia categories $9 / 29(31 \%)$ and WBC count more than $100 \times 10^{9} / \mathrm{L}$ found in $9 / 28(32.1 \%)$ of acute promyelocytic leukaemia with $\mathrm{t}(15 ; 17)$ and acute monoblastic and monocytic leukaemia categories (Table 3). 
Table 2 Comparison of the haematological variables between the patients group with mutations of the exon 12 of NPM 1 gene and those without

\begin{tabular}{|c|c|c|c|c|c|}
\hline \multirow[t]{2}{*}{ Variable } & \multicolumn{2}{|c|}{ Exon 12 of NPM 1 gene mutation } & \multirow{2}{*}{$\begin{array}{l}\text { Mean } \\
\text { difference }\end{array}$} & \multirow[t]{2}{*}{$t$ statistic (df) } & \multirow[t]{2}{*}{$p$ value $^{\mathrm{a}}$} \\
\hline & Present $20(22.2)$ & Absent $70(77.8)$ & & & \\
\hline WBC count $\left(\mathrm{X} 10^{9} / \mathrm{L}\right)$ & $\begin{array}{l}72.1 \pm 69.6 \\
1.60-270.0\end{array}$ & $\begin{array}{l}80.6 \pm 81.6 \\
1.3-375.5\end{array}$ & -8.56 & 31.7 & 0.38 \\
\hline $\mathrm{RBC}$ count $\left(\mathrm{X} 10^{12} / \mathrm{L}\right)$ & $\begin{array}{l}2.3 \pm 0.4 \\
1.6-3.1\end{array}$ & $\begin{array}{l}2.5 \pm 1.0 \\
1.0-5.4\end{array}$ & -0.13 & 74.2 & $0.019^{\mathrm{a}}$ \\
\hline $\mathrm{Hb}(\mathrm{g} / \mathrm{L})$ & $\begin{array}{l}71 \pm 11 \\
54-100\end{array}$ & $\begin{array}{l}76 \pm 22 \\
31-134\end{array}$ & -0.52 & 56.1 & $0.018^{\mathrm{a}}$ \\
\hline Hct (1/1) & $\begin{array}{l}0.22 \pm 0.04 \\
0.16-0.33\end{array}$ & $\begin{array}{l}0.24 \pm 0.07 \\
0.10-.039\end{array}$ & -0.02 & 48.1 & $0.014^{\mathrm{a}}$ \\
\hline MCV (fl) & $\begin{array}{l}91.7 \pm 9.1 \\
75.4-109-7\end{array}$ & $\begin{array}{l}93.5 \pm 11.9 \\
72.1-132.4\end{array}$ & -1.81 & 34.9 & 1.37 \\
\hline $\mathrm{MCH}(\mathrm{Pg})$ & $\begin{array}{l}33.3 \pm 15.3 \\
24.4-97.8\end{array}$ & $\begin{array}{l}33.9 \pm 16.1 \\
22.8-112.9\end{array}$ & -0.54 & 29.0 & 0.66 \\
\hline $\mathrm{MCHC}(\mathrm{g} / \mathrm{L})$ & $\begin{array}{l}329 \pm 23 \\
266-366\end{array}$ & $\begin{array}{l}316 \pm 33 \\
130-376\end{array}$ & 103 & 38.83 & 0.08 \\
\hline $\begin{array}{l}\text { Platelet count } \\
\left(\mathrm{X} 10^{9} / \mathrm{L}\right)\end{array}$ & $\begin{array}{l}116.4 \pm 158.6 \\
8.0-700.0\end{array}$ & $\begin{array}{l}73.1 \pm 76.8 \\
4.0-490.0\end{array}$ & 43.28 & 21.01 & $0.006^{\mathrm{a}}$ \\
\hline BM Blast (\%) & $\begin{array}{l}75.4 \pm 14.1 \\
34-90\end{array}$ & $\begin{array}{l}60 \pm 27 \\
6.0-97\end{array}$ & 15.94 & 54.70 & $0.001^{\mathrm{a}}$ \\
\hline
\end{tabular}

$H c t$ haematocit, $M C V$ mean corpuscular volume, $M C H$ mean corpuscular haemoglobin, $M C H C$ mean corpuscular haemoglobin concentration

${ }^{\mathrm{a}}$ Independent $t$ test, Values represent either numbers (percentages) or as mean \pm S.D. (minimum-maximum)
The incidence of all forms of NPM1 mutations varied between 25 and $35 \%$ in the literature while the reported NPM1-A type of mutation was 19.1-20.3\% [7, 21, 30]. Mutation in the exon-12 of the NPM1 gene was reported in $28.2 \%$ of the overall population, including $1 / 1(100 \%)$ of AML, with minimal differentiated,11/27 (40.7\%) of AML without maturation, 11/46 (23.9\%) of AML with maturation, $0 / 29(0 \%)$ of acute promyelocytic leukaemia with $\mathrm{t}(15 ; 17), 2 /$ $9(22.2 \%)$ of acute myelomonocytic leukaemia, $18 / 39(46.2 \%)$ of acute monoblastic and monocytic leukaemia and 1/5 (20.0\%) of acute erythroid leukaemia [33].

In agreement with previously reported frequencies [25], the NPM1 gene mutations in this study was detected in 20/90 (22.2\%) AML patients with or without abnormal karyotypes (Table 3). Three types of exon 12 mutation were identified at positions 27898 (rs1059404), 27998 and 28027 (rs34351976). Two of the mutations fall upstream $(\mathrm{C} 27806 \mathrm{~T})$ and downstream (A28193G) of the exon12 region were removed from the analysis to rule out false or lowconfidence mutations resulting from noise (Fig. 2).

In a study conducted in Japan, NPM1 mutations were reported in $24.9 \%$ adults with de novo AML and $47.4 \%$ AMLs with a normal karyotype, in seven patients (11.7\%) among another group of 60 Japanese patients and in Taiwan; the incidences were $19.1 \%$ and $40.3 \%$ in two local groups [13, $34,35]$. It was reported that among the Korean patients, $38.3 \%$ had NPM1 mutation [30] [35]. Most studies for NPM1 mutation status in Asians have recruited AML patients with or without abnormal karyotypes [20,36]. The mutation in the NPM1 gene in Western population occurs with an overall frequency of $25-35 \%[1,2]$. NPM1 mutations have been reported in 50-60\% of adults with de novo AML, especially in those of a normal karyotype.

Unexpectedly, the lack of relationship between the WBC count and the mutation status (Table 2) was consistent with the result from another study in Malaysia and with another study conducted among the Western population [37]. The difference in the incidence of NPM1 mutation between the populations suggests that leukaemia in Asian patients may differ from that of Western patients in pathogenesis and biological characteristics [24, 38, 39]. Based on these findings, this study carries a significant impact both at the local and the regional levels.

Unlike prior research findings [21, 22], this study revealed no correlation between the immunophenotyping variables (CD45, CD34, CD33, cMPO, CD13, CD117, HLADR, CD14, CD11b, CD11c, CD64, CD16, CD15, CD3, CD7, CD2, CD56, CD79a, $\mathrm{CD} 19, \mathrm{CD} 71, \mathrm{CD} 38$ and CD4) and the mutation status in exon 12 of the NPM1 gene in patients with AML.

Although 90 patients with de novo AML were enrolled in this study, the sample size was not sufficiently large to reflect the actual population of adults and paediatric patients with AML in Malaysia. This study is the first to investigate the correlation of the HL grading score with the frequency of the NPM1 gene mutation in Malaysian patients with AML with or without abnormal karyotypes. 


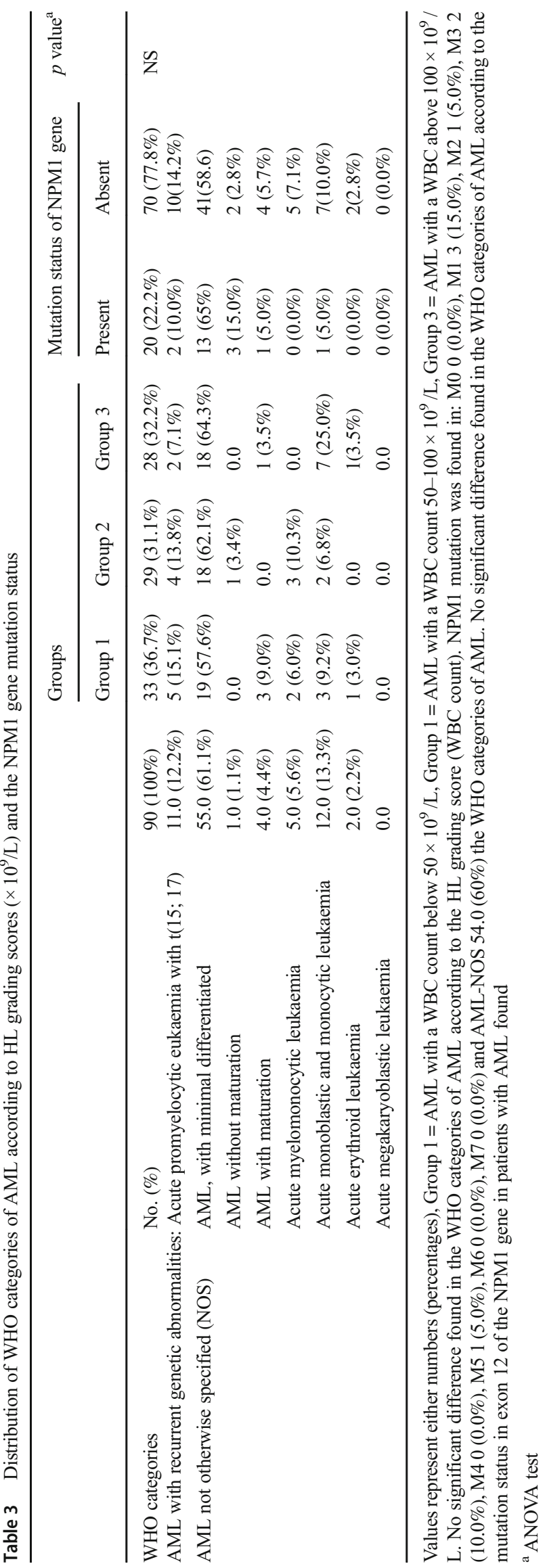

\section{Conclusions and recommendations}

In spite of being clinically defined, the current two cut off values defining the HL (total WBC count of 50-100 and $\geq$ $100 \times 10^{9} / \mathrm{L}$ ) seem to be molecularly unreliable, based on NPM1 gene mutation. Contrary to expectation, no statistically significant difference was found in the WBC counts; according to the NPM1 gene, the mutation status among the studied patients. Also, there were also no significant differences in the WHO classification categories according to the HL grading score. The association between the WBC count and the mutation status was absent. The difference in the incidence of NPM1 mutation among different populations suggests that the cellular behaviour and pathogenic mechanisms of leukaemia in Malaysian patients might vary from that of Western patients in pathogenesis and biological characteristics. There is still much to be investigated about the correlation of the current HL grading scores with the underlying genetic alteration and interaction with other mutations such as FLT3, NRAS, JAK 2 and C-KIT.

Acknowledgments We are in indebted to the staff in the Haematology unit - Pathology Department and molecular haematology laboratory at Hospital Kuala Lumpur (HKL) for storage of the samples and DNA extraction. Thanks are extended to Mr. Mohammed Izwan Bin Ismail for his assistance in the samples processing.

Funding information This study was supported by a grant from the University Sultan Zainal Abidin (UniSZA), Kuala TerengganuMalaysia (UniSZA/13/GU (023)).

\section{Compliance with ethical standards}

Ethical approval was obtained from UniSZA (UniSZA/C/2/CRIM/628-1 (26)) and National Medical Research Register (NMRR-13-1487-1712).

Conflict of interest The authors of this paper have no conflicts of interest, including specific financial interests, relationships, and/ or affiliations relevant to the subject matter or materials included.

\section{References}

1. Ferrara F, Schiffer CA (2013) Acute myeloid leukemia in adults. Lancet 381:484-495

2. Watt CD, Bagg A (2010) Molecular diagnosis of acute myeloid leukemia. Expert Rev Mol Diagn 10:993-1012

3. Grisendi S, Mecucci C, Falini B, Pandolfi PP (2006) Nucleophosmin and cancer. Nat Rev Cancer 6:493-505

4. Meani N, Alcalay M (2009) Role of nucleophosmin in acute myeloid leukemia. Anticancer Ther 9:1283-1294

5. Falini B, Mecucci C, Tiacci E, Alcalay M, Rosati R, Pasqualucci L et al (2005) Cytoplasmic Nucleophosmin in acute myelogenous leukemia with a normal karyotype. N Engl J Med 352:254-256

6. Borer RA, Lehner CF, Eppenberger HM, Nigg EA (1989) Major nucleolar proteins shuttle between nucleus and cytoplasm. Cell 56:379-390 
7. Thiede C, Koch S, Creutzig E, Steudel C, Illmer T, Schaich M et al (2006) Prevalence and prognostic impact of NPM1 mutations in1485 adult patients with acute myeloid leukemia (AML). Blood 107:4011-4020

8. Renneville A, Roumier C, Biggio V, Nibourel O, Boissel N, Fenaux $\mathrm{P}$ et al (2008) Cooperating gene mutations in acute myeloid leukemia: a review of the literature. Leukemia. 22:915-931

9. HJMd J, PJM V, ESJMd B, Schuringa JJ, Ossenkoppele G (2011) Prognostic impact of white blood cell count in intermediate risk acute myeloid leukemia: relevance of mutated NPM1 and FLT3ITD. Haematologica 96:1310-1317

10. Betz BL, Hess JL (2010) Acute myeloid leukemia diagnosis in the 21st century. Arch Pathol Lab Med. 134:1427-1433

11. Liu Y, He P, Liu F, Shi L, Zhu H, Zhao J et al (2014) Prognostic significance of NPM1 mutations in acute myeloid leukemia: a meta-analysis. Molecular And Clinical Oncology 2:275-281

12. Boissel N, Renneville A, Biggio V, Philippe N, Thomas X, Cayuela $\mathrm{J}-\mathrm{M}$ et al (2005) Prevalence, clinical profile, and prognosis of NPM mutations in AML with normal karyotype. Blood 106:3618-3620

13. Vardiman JW, Je T, Arber DA, Brunning RD, Borowitz MJ, Porwit A et al (2009) The 2008 revision of the World Health Organization (WHO) classification of myeloid neoplasms and acute leukemia: rationale and important changes. Blood. 114:937-951

14. Morris SW, Kirstein MN, Valentine MB, Dittmer KG, Shapiro DN, Saltman DL et al (1994) Fusion of a kinase gene, ALK, to a Nucleolar protein gene, NPM, in non-Hodgkin's lymphoma. SCIENCE 263

15. Piccirillo N, Laurenti L, Chiusolo P, Sora F, Bianchi M, Matteis SD et al (2009) Reliability of leoucostasis grading score to identify patients with high risk HL. Am J Hematol 84:381-382

16. Hussein UY, Yusoff NM (2011) HL in acute and chronic leukaemias (myeloid \& lymphoid types). Biohealth Science Bulletin 3: 20-28

17. Novotny JR, Müller-Beissenhirtz H, Herget-Rosenthal S, Kribben A, Dührsen U (2008) Grading of symptoms in hyperleukocytic leukaemia: a clinical model for the role of different blast types and promyelocytes in the development of leukostasis syndrome. European Journal of Haematology. 74:501-510

18. Porcu P, Cripe LD, Ng EW, Bhatia S, Danielsonb CM, Mccarthy AOALJ (2000) Hyperleukocytic leukemias and leukostasis: a review of pathophysiology, clinical presentation and management. Leukemia \& Lymphoma 39:1-18

19. Döhner K, Schlenk RF, Habdank M, Scholl C, Rücker FG, Corbacioglu A et al (2005) Mutant nucleophosmin (NPM1) predicts favorable prognosis in younger adults with acute myeloid leukemia and normal cytogenetics: interaction with other gene mutations. Blood. 106:3740-3746

20. Huang L, Zhou K, Yang Y, Shang Z, Wang J, Wang D et al (2012) FLT3-ITD-associated gene-expression signatures in NPM1mutated cytogenetically normal acute myeloid leukemia. Int $\mathrm{J}$ Hematol 96:234-240

21. Chen C-Y, Chou W-C, Tsay W, Tang J-L, Yao M, Huang S-Y et al (2013) Hierarchical cluster analysis of immunophenotype classify AML patients with NPM1 gene mutation into two groups with distinct prognosis. BMC Cancer 13:1-9

22. Oelschlaegel U, Koch S, Mohr B, Schaich M, Falini B, Ehninger G et al (2010) Rapid flow cytometric detection of aberrant cytoplasmic localization of nucleophosmin (NPMc) indicating mutant NPM1 gene in acute myeloid leukemia. Leukemia. 24:1813-1816

23. Mardis ER, Ding L, Dooling DJ, Larson DE, McLellan MD, Chen $\mathrm{K}$ et al (2009) Recurring mutations found by sequencing an acute myeloid leukemia genome. N Engl J Med 361:1058-1066
24. Falini B, Bolli N, Liso A, Martelli M, Mannucci R, Pileri S et al (2009) Altered nucleophosmin transport in acute myeloid leukaemia with mutated NPM1: molecular basis and clinical implications. Leukemia. 23:1731-1743

25. Kuhnl A, Grimwade D (2012) Molecular markers in acute myeloid leukaemia. Int J Hematol 96:153-163

26. Chen W, Rassidakis GZ, Medeiros LJ (2006) Nucleophosmin gene mutations in acute myeloid leukemia. Arch Pathol Lab Med 130: $1687-1692$

27. Cazzaniga G, Dell'Oro MG, Mecucci C, Giarin E, Masetti R, Rossi $\mathrm{V}$ et al (2005) Nucleophosmin mutations in childhood acute myelogenous leukemia with normal karyotype. Blood. 106:1419-1422

28. Rau R, Brown P (2009) Nucleophosmin (NPM1) mutations in adult and childhood acute myeloid leukemia: towards definition of a new leukemia entity. Hematol Oncol 27:171-181

29. Verhaak RGW, Goudswaard CS, Putten W, Bijl MA, Sanders MA, Hugens W et al (2005) Mutations in nucleophosmin (NPM1) in acute myeloid leukemia (AML): association with other gene abnormalities and previously established gene expression signatures and their favorable prognostic significance. Blood 106:3747-3754

30. Boonthimat C, Thongnoppakhun W, Auewarakul CU (2008) Nucleophosmin mutation in southeast Asian acute myeloid leukemia: eight novel variants, FLT3 coexistence and prognostic impact of NPM1/FLT3 mutations. Haematologica. 93:1565-1569

31. Ruan G-R, Li J-L, Qin Y-Z, Li L-D, Xie M, Chang Y et al (2009) Nucleophosmin mutations in Chinese adults in acute myelogenous leukemia. Ann Hematol 88:159-166

32. Park BG, Chi H-S, Park S-J, Min SK, Jang S, Park C-J et al (2012) Clinical implications of non-A-type NPM1 and FLT3 mutations in patients with normal karyotype acute myeloid leukemia. Acta Haematol 127:63-71

33. Yan L, Chen S, Liang J, Feng Y, Cen J, He J (2007) Analysis of NPM1 gene mutations in Chinese adults with acute myeloid leukemia. Int J Hematol 86:143-146

34. Chou W-C, Tang J-L, Lin L-I, Yao M, Tsay W, Chen C-Y et al (2006) Nucleophosmin mutations in de novo acute myeloid leukemia: the age-dependent incidences and the stability during disease evolution. Cancer Res 66:3310-3316

35. Suzuki R, Onizuka M, Kojima M, Shimada M, Okamura K (2007) Prognostic significance of FLT3 internal tandem duplication and NPM1 mutations in acute myeloid leukemia in an unselected patient population. Int J Hematol 86:422-428

36. Suzuki T, Kiyoi H, Ozeki K, Tomita A, Yamaji S, Suzuki R et al (2005) Clinical characteristics and prognostic implications of NPM1 mutations in acute myeloid leukemia. Blood. 106:2854 2861

37. Döhner K, Döhner H (2008) Molecular characterization of acute myeloid leukemia. Haematologica. 93:976-982

38. Heather JM, Chain B (2016) The sequence of sequencers: the history of sequencing DNA. Genomics 107:1-8

39. Falini B, Sportoletti P, Martelli MP (2009) Acute myeloid leukemia with mutated NPM1: diagnosis, prognosis and therapeutic perspectives. Curr Opin Oncol 21:573-581

Limitations of this study: this study would still have a limited influence at the global level.

Publisher's note Springer Nature remains neutral with regard to jurisdictional claims in published maps and institutional affiliations. 